\title{
Impact Evaluation of Soil and Water Conservation Measures on Groundwater Recharge at Pedgaon Watershed
}

\author{
J. P. Shewale ${ }^{1 *}$, B. W. Bhuibhar ${ }^{2}$ and S. C. Mundhe ${ }^{1}$ \\ ${ }^{1}$ College of Agricultural Engineering \& Technology, VNMKV, Parbhani, Maharashtra, India \\ ${ }^{2}$ Department of Soil \& water Conservation Engineering, College of Agricultural Engineering \\ \& Technology, VNMKV, Parbhani, Maharashtra, India \\ *Corresponding author
}

\section{A B S T R A C T}

\section{Keywords}

Watershed, Ground

Water, Soil and

Water conservation,

Rainfall,

conservation

measures

\section{Article Info}

Accepted:

07 January 2021

Available Online:

10 February 2021

\begin{abstract}
Impact evaluation of soil and water conservation measures on groundwater recharge conducted at Pedgaon watershed, Dist. Parbhani in year 2019-2020 by considering implemented soil and water conservation measures. To evaluate the impact of soil and water conservation it is need to compare pre development data and post development data of Pedgaon watershed. For this purpose, percentage of ground water recharge out of total rainfall in year 2014-2015 and 2019-2020 in Pedgaon watershed was compared. Well inventory data such as depth of water in the well from bottom of well was collected for the year 2014-2015 and year 2019-2020. To evaluate the percentage of ground water recharge out of total rainfall with the help of Watertable Fluctuation Method was used. In year 2014-2015 total rainfall in Pedgaon watershed was $280 \mathrm{~mm}$ out of which $48.3 \mathrm{~mm}$ was recharged to groundwater table and in year 2019-2020 total rainfall in Pedgaon watershedwas $586.1 \mathrm{~mm}$ out of which $143.00 \mathrm{~mm}$ was recharged to groundwater table. It was concluded that, in year 2014-2015 out of total rainfall $17.24 \%$ of rainfall recharged to groundwater table and in year 2019-2020 out of total rainfall $24.33 \%$ of rainfall recharged to groundwater table.
\end{abstract}

\section{Introduction}

Agricultural production is largely depending on rainfall and groundwater i.e. it is vital basis intended for irrigation. There is an impressive augmentation in annual food production in the country as an appropriately utilization of water over the years. With the inadequate scope of development of irrigation potential and rainwater management and conservation plays a vital function to an enhancement the groundwater and surface water in favor of household and agriculture utilization. Therefore, an efficient conservation as well as scientific management to harvest water and percolation within ground to recharge groundwater is crucial in favor of best possible utilization intended in favor of crop production and rising productivity. In support of proficient and judicious utilization of rainwater, watershed development be the simply approach to 
formulate positive results such as increase groundwater recharge and crop production (Gore et al., 2002).

Watershed development programme launched by Government of Maharashtra, 'Jalyukt Shivar Abhiyan' plan to soil and water conservation and management along with groundwater table increment for droughtaffected villages in Maharashtra state. With the passing time, the watershed development programme has been going strong and very effective with village/watershed development and making the watershed development programme one of the largest Government initiatives for people.

It is now a well-recognized piece of information that water is a limited and susceptible resource, and it must be used proficiently and in an ecologically sound manner in favor of present as well as future generations. It is precisely said that groundwater will be long-term test of this generation's intelligence in water conservation and land management (Natarajan et al., 2018).

This research paper deals with the estimation of changes in groundwater recharge after construction of soil and water conservation measures in Pedgaon watershed.

\section{Materials and Methods}

\section{Description of Pedgaon watershed}

The Soil and water conservation measures at Pedgaon watershed were completed for the duration in year 2015-16 by Government of Maharashtra under 'Jalyukt Shivar Abhiyan' programme.

\section{Location of study}

Pedgaon watershed located in talukaParbhani, district-Parbhani, of Maharashtra state. Pedgaon watershed situated at $19 \mathrm{~km}$ towards west from Parbhani. It is located at 19032' latitude and 76066' longitude.

\section{Area, soil and topography of Pedgaon watershed}

The geographical area of Pedgaon watershed is 3263 ha out of which 3060 ha cultivable land and 203 ha of land is not under cultivation. Population of Pedgaon village was 11757 as per Population Census 2011. The soil is of two types i.e. black cotton and medium black available in Pedgaon watershed. Topography of land is flat to undulating. The general slope of land is $1 \%$ to $4 \%$ while slope of non cultivable area ranges from $3 \%$ to $10 \%$ (Report of Pedgaon watershed, 2018).

\section{Climate in Pedgaon watershed}

The Pedgaon watershed falls in the semi arid region where less seasonal rainfall and high evaporative demand. The annual rainfall in year 2019 was $586.1 \quad \mathrm{~mm}$ (http://maharain.gov.in/). In Pedgaon watershed, rainfall pattern was irregular as well as changes from year to year. The temperature of Pedgaon watershed normally recorded for the duration of month of AprilMay was maximum of $43^{\circ} \mathrm{C}$ while lowest temperature of $15^{\circ} \mathrm{C}$ recorded for the duration of month of December-January of winter season.

\section{Well inventory}

\section{Measurement of water level in well}

In the watershed area of Pedgaon eight wells situated in the zone of influence and out of zone of influence of the soil and water conservation measures, selected randomly for water level monitoring. Water levels in the wells were monitored fortnightly from period 
June 2019 to February 2020. The water levels of selected well before development and after development of soil and water conservation measures were compared for assessing the impact of soil and water conservation measures on changes in water level in wells i.e. ground water recharge by increasing groundwater table. Also, area of influence of different soil and water conservation measures were observed by the effect of soil and water conservation measures on ground water recharge according to water level changes with respect to rainfall amount. Also, information related to period of which water available in well for irrigation at pre development and post development of the soil and water conservation measures was collected (Ghule et al., 2006).

Eight wells were selected on the basis to collect the data regarding water levels on downstream side of soil and water conservation measures at Pedgaon watershed. Out of eight open wells, three wells W 1, W 2 and $\mathrm{W} 3$ were located on downstream side of cement nala bund, three wells W 4, W 5 and W 6 were located downstream side of farm pond and two wells $\mathrm{W} 7$ and $\mathrm{W} 8$ were located on the downstream side of earthen nala bund. Using measuring tape water level in the open wells from bottom of wells was measured fortnightly. The observed water levels of the selected wells after Pedgaon watershed development were compared with water levels before development of the Pedgaon watershed.

\section{Groundwater recharge by using water table fluctuation method}

Groundwater recharge was estimated by using water table fluctuation method with respect to rainfall in particular watershed area. The watertable fluctuation method mainly/comprehensively used method to groundwater recharge evaluation. The
Groundwater Estimation Committee recommended groundwater table fluctuation method for estimating the groundwater recharge. The method is scientific and takes into account the changes of groundwater level fluctuation and specific yield, which were more, realistic and directly measurable, unlike other approaches/methods, where assumptions were to be made for most of the components (Groundwater Resource Estimation Committee Report, 1997). June 2019 to February 2020 ground water table fluctuation data of the Pedgaon watershed were used for groundwater recharge estimation using formula (Pendke et al.,2018),

$\mathrm{Pi}=\mathrm{h} \times \mathrm{Sy}$

Where,

$\mathrm{Pi}=$ Precipitation that percolates to groundwater recharge, $\mathrm{cm} \mathrm{h}=$ Change in water level

Sy= Specific yield

The changes in water level were obtained from the water level information which was measured fortnightly, specific yield was considered as 0.023 (Groundwater Resource Estimation Committee Report, 1997). Further the groundwater recharge in terms of percent of corresponding total rainfall utilized for groundwater recharge at different well locations was estimated at pre development and post development of Pedgaon watershed.

\section{Results and Discussion}

For assessing the impact of soil and water conservation measures on ground water recharge, randomly selected eight open wells situated in Pedgaon watershed area and located on downstream side of the soil and water conservation measures. Selection of 
well on the basis of, the distance of well from the soil and water conservation measures and its effect on groundwater recharge was evaluated by measuring the water level in the well from bottom of well (Fig. 1 and Table 14).

\section{Groundwater recharge by using water table fluctuation method}

Groundwater recharge possible simply through impounding excess runoff to percolate in ground and it depends on rainfall pattern. Fortnightly watertable fluctuations from 1 June to 15 November and recharge in terms of percentage of corresponding amount of rainfall for 8 wells in Pedgaon watershed for the duration of the year before Pedgaon watershed development (2014- 2015) presented in Table 3 For the convenience all values were converted into same unit i.e. centimeter $(\mathrm{cm})$.From Table 3 observed that, $4.025 \mathrm{~cm}-5.405 \mathrm{~cm}$ of precipitation was recharged to the groundwater table in selected wells in Pedgaon watershed. It was also observed that 14.37 percent -18.89 percent of total rainfall received was percolate to recharging the groundwater table. From Table 3 concluded that, average 17.24 percent of total rainfall percolates to recharging the groundwater in Pedgaon watershed for the duration of year 2014-15 previous to the water shed development.

Table.1 Details of soil and water conservation measures under Jalyukt Shivar Abhiyan at Pedgaon watershed

\begin{tabular}{|c|c|c|c|}
\hline $\begin{array}{c}\text { Sr. } \\
\text { No. }\end{array}$ & $\begin{array}{c}\text { Name of } \\
\text { Structures }\end{array}$ & $\begin{array}{c}\text { Area/No. of } \\
\text { Structures }\end{array}$ & $\begin{array}{c}\text { Area/No. of measures } \\
\text { selected for evaluation }\end{array}$ \\
\hline $\mathbf{1 .}$ & Graded Bunds & 250 ha & $\mathbf{5 0}$ ha \\
\hline $\mathbf{2 .}$ & Farm Ponds & 35 & $\mathbf{5}$ \\
\hline $\mathbf{3 .}$ & $\begin{array}{c}\text { Cement Nala } \\
\text { Bunds }\end{array}$ & 22 & $\mathbf{4}$ \\
\hline $\mathbf{4 .}$ & $\begin{array}{c}\text { Earthen Nala } \\
\text { Bund }\end{array}$ & $\mathbf{1}$ & $\mathbf{1}$ \\
\hline
\end{tabular}

Table.2 Details of wells selected for observations in Pedgaon watershed in year 2019

\begin{tabular}{|c|c|c|c|}
\hline Well No. & Depth of well (m) & $\begin{array}{c}\text { Distance from water } \\
\text { harvesting measures }(\mathbf{m})\end{array}$ & $\begin{array}{c}\text { Diameter of well } \\
(\mathbf{m})\end{array}$ \\
\hline W1 & 11 & 35 & $\mathbf{2 5}$ \\
\hline W2 & 14 & 490 & $\mathbf{7}$ \\
\hline W3 & 15 & 190 & $\mathbf{9}$ \\
\hline W4 & 16 & 80 & $\mathbf{8}$ \\
\hline W5 & 14 & 470 & $\mathbf{7 . 5}$ \\
\hline W6 & 14 & 32 & $\mathbf{6}$ \\
\hline W7 & 14 & 105 & $\mathbf{6 . 5}$ \\
\hline W8 & $\mathbf{1 6}$ & $\mathbf{6 0}$ & $\mathbf{1 0}$ \\
\hline
\end{tabular}


Table.3 Total ground water recharge in wells located in Pedgaon watershed in year 2014- 2015

\begin{tabular}{|c|c|c|c|c|c|c|}
\hline $\begin{array}{c}\text { Sr. } \\
\text { No. }\end{array}$ & $\begin{array}{c}\text { Rainfall } \\
\text { Period }\end{array}$ & $\begin{array}{c}\text { Total } \\
\text { Rainfa } \\
\text { ll(cm) }\end{array}$ & $\begin{array}{c}\text { Well } \\
\text { No. }\end{array}$ & $\begin{array}{c}\text { Difference in } \\
\text { water level }(\mathbf{c m})\end{array}$ & $\begin{array}{c}\text { Pi } \\
(\mathbf{c m})\end{array}$ & $\begin{array}{c}\text { Recharge Percentage } \\
\text { of total rainfall (\%) }\end{array}$ \\
\hline $\mathbf{1}$ & $\begin{array}{c}\text { 1 June to 15 } \\
\text { November }\end{array}$ & 28 & 1 & 220 & 5.06 & $\mathbf{1 8 . 0 7}$ \\
\hline $\mathbf{2}$ & $\begin{array}{c}\text { 1 June to 15 } \\
\text { November }\end{array}$ & 28 & 2 & 230 & 5.29 & $\mathbf{1 8 . 8 9}$ \\
\hline $\mathbf{3}$ & $\begin{array}{c}\text { 1 June to 15 } \\
\text { November }\end{array}$ & 28 & 3 & 180 & 4.14 & $\mathbf{1 4 . 7 8}$ \\
\hline $\mathbf{4}$ & $\begin{array}{c}\text { 1 June to 15 } \\
\text { November }\end{array}$ & 28 & 4 & 230 & 5.29 & $\mathbf{1 8 . 8 9}$ \\
\hline $\mathbf{5}$ & $\begin{array}{c}\text { 1 June to 15 } \\
\text { November }\end{array}$ & 28 & 5 & 235 & 5.405 & $\mathbf{1 9 . 3 0}$ \\
\hline $\mathbf{6}$ & $\begin{array}{c}\text { 1 June to 15 } \\
\text { November }\end{array}$ & 28 & 6 & 175 & 4.025 & $\mathbf{1 4 . 3 7}$ \\
\hline $\mathbf{7}$ & $\begin{array}{c}\text { 1 June to 15 } \\
\text { November }\end{array}$ & 28 & 7 & 220 & 5.06 & $\mathbf{1 8 . 0 7}$ \\
\hline $\mathbf{8}$ & $\begin{array}{c}\text { 1 June to 15 } \\
\text { November }\end{array}$ & 28 & 8 & 190 & 4.37 & $\mathbf{1 5 . 6 0}$ \\
\hline & \multicolumn{2}{|c|}{ Average } & & $\mathbf{4 . 8 3}$ & $\mathbf{1 7 . 2 4}$ \\
\hline
\end{tabular}

Table.4 Ground water recharge in wells located in Pedgaon watershed in year 2019-2020

\begin{tabular}{|c|c|c|c|c|c|c|}
\hline $\begin{array}{c}\text { Sr. } \\
\text { No. }\end{array}$ & $\begin{array}{c}\text { Rainfal } \\
\text { I } \\
\text { Period }\end{array}$ & $\begin{array}{c}\text { Total } \\
\text { Rainfa } \\
\text { l }(\mathbf{c m})\end{array}$ & $\begin{array}{c}\text { Well } \\
\text { No. }\end{array}$ & $\begin{array}{c}\text { Difference in } \\
\text { water level }(\mathbf{c m})\end{array}$ & $\begin{array}{c}\text { Pi } \\
(\mathbf{c m})\end{array}$ & $\begin{array}{c}\text { Recharge Percentage } \\
\text { of total rainfall }\end{array}$ \\
\hline $\mathbf{1}$ & $\begin{array}{c}\text { 1 June to 15 } \\
\text { November }\end{array}$ & 58.61 & 1 & 720 & 16.56 & $\mathbf{2 8 . 2 5}$ \\
\hline $\mathbf{2}$ & $\begin{array}{c}\text { 1 June to 15 } \\
\text { November }\end{array}$ & 58.61 & 2 & 560 & 12.80 & $\mathbf{2 1 . 9 7}$ \\
\hline $\mathbf{3}$ & $\begin{array}{c}\text { 1 June to 15 } \\
\text { November }\end{array}$ & 58.61 & 3 & 530 & 12.19 & $\mathbf{2 0 . 7 9}$ \\
\hline $\mathbf{4}$ & $\begin{array}{c}\text { 1 June to 15 } \\
\text { November }\end{array}$ & 58.61 & 4 & 550 & 12.65 & $\mathbf{2 1 . 5 8}$ \\
\hline $\mathbf{5}$ & $\begin{array}{c}\text { 1 June to 15 } \\
\text { November }\end{array}$ & 58.61 & 5 & 590 & 13.57 & $\mathbf{2 3 . 1 5}$ \\
\hline $\mathbf{6}$ & $\begin{array}{c}\text { 1 June to 15 } \\
\text { November }\end{array}$ & 58.61 & 6 & 795 & 18.28 & $\mathbf{3 1 . 1 9}$ \\
\hline $\mathbf{7}$ & $\begin{array}{c}\text { 1 June to 15 } \\
\text { November }\end{array}$ & 58.61 & 7 & 685 & 15.75 & $\mathbf{2 6 . 8 8}$ \\
\hline $\mathbf{8}$ & $\begin{array}{c}\text { 1 June to 15 } \\
\text { November }\end{array}$ & 58.61 & 8 & 550 & 12.65 & $\mathbf{2 1 . 5 8}$ \\
\hline
\end{tabular}


Fig.1 Changes in percent of ground water recharge after watershed development

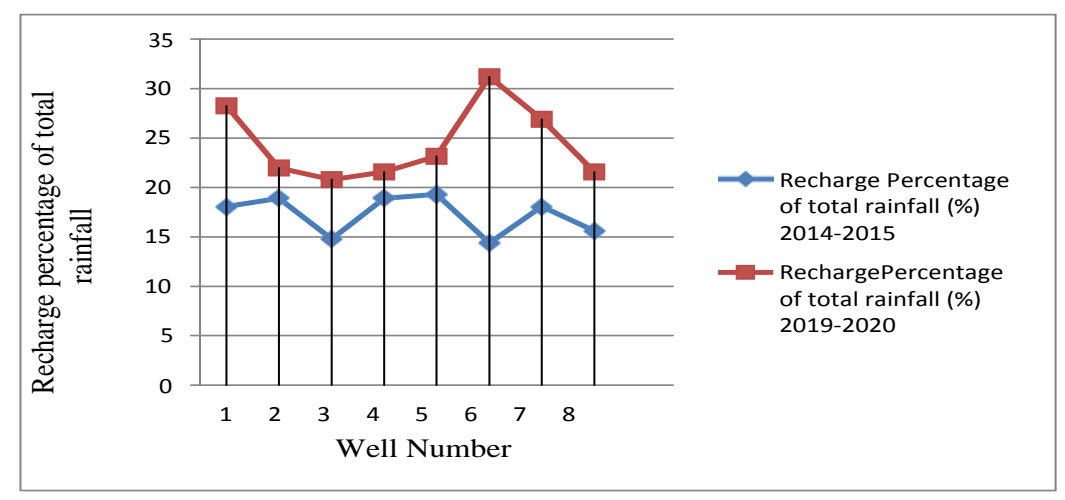

Fortnightly water table fluctuations from 1 June to 15 November and recharge in terms of percentage of corresponding amount of rainfall for 8 wells in Pedgaon watershed for the duration of the year before Pedgaon watershed development (2019-2020) presented in Table 4 For the convenience all values were converted into same unit i.e. centimeter $(\mathrm{cm})$.From Table 4 observed that, total depth of precipitation between $12.19 \mathrm{~cm}$ - $18.28 \mathrm{~cm}$ was percolate to ground water recharge to increased groundwater table. It was also observed that 20.79 percent -31.19 percent of total rainfall received was percolate to recharging the groundwater table. From Table 4, concluded that, average 24.33 percent rainfall percolate to recharging the groundwater table in Pedgaon watershed for the duration of year 2019-20 after the Pedgaon watershed development.

From Table 3 and Table 4, concluded that, after watershed development amount of precipitation percolate to groundwater recharge increased from $4.83 \mathrm{~cm}$ to $14.30 \mathrm{~cm}$ in Pedgaon watershed. Also, percent of total rainfall percolate to ground water recharge increased from $17.24 \%$ to $24.33 \%$ due to Pedgaon watershed development.

In conclusion the total annual rainfall in year 2014-15 was $280 \mathrm{~mm}$ at Pedgaon watershed. In pre development (2014-15) of Pedgaon watershed average $48.30 \mathrm{~mm}$ rainfall utilized for groundwater recharge i.e. $17.24 \%$ of total rainfall for the duration of year 2014-15. Total annual rainfall in year 2019-20 was $586.1 \mathrm{~mm}$. In post development (2019-20) of Pedgaon watershed average $143 \mathrm{~mm}$ rainfall utilized for groundwater recharge i.e. $24.33 \%$ of total rainfall for the duration of year 201920. Overall, subsequent to the development of Pedgaon watershed percent of total rainfall utilized for groundwater recharge improved from $17.24 \%$ to $24.33 \%$ because of soil and water conservation measures development in Pedgaon watershed.

\section{Acknowledgement}

I acknowledge the, Department of Agriculture, Parbhani, Government of Maharashtra, for providing necessary data and support for my research work. It is my proud privilege to express my devout gratitude and indebtedness to my major advisor Prof. B. W. Bhuibhar, Associate Professor, Department of SWCE, CAET, VNMKV, Parbhani, Maharashtra for his thoughtful guidance, constant fomenting and impeccable advices throughout out the research work in time.

\section{References}

Ghule S.B., Pawar S.N., Jadhav S.B., Ramteke R.T. and Bhuibhar B.W. (2006), Performance Evaluation of Nala 
Bund. Karnataka Journal Agriculture Science, Vol. 19 (1): 90-96.

Gore K. P., Pendke M.S. and Jallawar D. N. (2002), Impacts assessment of soil and water conservation structures in Wagarwadi watershed. Karanataka Journal of Agriculture Science, Vol. 13 (3): 676-681.

Natarajan P., Kottiswaran S. V., Balasubramanian A. and Palanikumaran B. (2018), Groundwater Recharge Estimation Using Comparison of
Methods in Sirumugai Area of Coimbatore, Tamil Nadu, India. International Journal Current Microbiology Applied Science. Vol. 7(6):1433-1440.

Pendke M.S., Asewar B.V., Samindre M.S., Ravindra G. and Narsimlu B. (2018), Water Budgeting of Babhulgaon Micro Watershed under Deficit Rainfall Years. Indian Journal Dryland Agriculture Res. \& Development Vol. 33(2):43-49.

\section{How to cite this article:}

Shewale, J. P., B. W. Bhuibhar and Mundhe, S. C. 2021. Impact Evaluation of Soil and Water Conservation Measures on Groundwater Recharge at Pedgaon Watershed. Int.J.Curr.Microbiol.App.Sci. 10(02): 606-612. doi: https://doi.org/10.20546/ijcmas.2021.1002.072 